\title{
Krónikus teljes koronáriaokklúzió transthoracalis echokardiográfiás diagnózisa
}

\author{
Pálinkás Attila1', Ruzsa Zoltán², Kákonyi Kornél Manó2, Molnár Dorottya', \\ ifj. Csanády Miklós', Pálinkás Eszter Dalma², Ungi Imre²
}

\author{
${ }^{1}$ Csongrád-Csanád Megyei Egészségügyi Ellátó Központ, Hódmezővásárhely-Makó, Belgyógyászati Osztály, \\ Hódmezővásárhely \\ ²Szegedi Tudományegyetem, Általános Orvostudományi Kar, Szent-Györgyi Albert Klinikai Központ, \\ Belgyógyászati Klinika, Szeged \\ Levelezési cím: \\ Dr. Pálinkás Attila, Csongrád-Csanád Megyei Egészségügyi Ellátó Központ, Hódmezővásárhely-Makó, Belgyógyászati Osztály \\ 6800 Hódmezővásárhely, Dr. Imre J u. 2. E-mail: palinkasa@hotmail.com
}

Közleményünkben egy 59 éves férfi beteg esetét mutatjuk be, akinél a krónikus effort mellkasi panaszok hátterében a transthoracalis Doppler-echokardiográfiás vizsgálat (TTDE) normális bal kamrai szisztolés funkció mellett a ramus descendens anteriorban (RDA) retrográd artériás koronáriaáramlást igazolt. A TTDE-lelet alapján felmerült az RDA krónikus teljes okklúziójának (CTO) erős gyanúja. Az invazív koronarográfia során a proximális RDA krónikus elzáródása mellett a jobb koronária felől fejlett epikardiális kollaterális rendszer (CC 2) volt kimutatható. Az elektív invazív beavatkozás során az RDA CTO-t sikeresen megnyitottuk, amelyet követően a beteg panaszai megszűntek. A TTDE a reverz koronáriaáramlás megszűnését és a fiziológiás artériás koronáriaáramlási irány helyreállását igazolta.

Kulcsszavak: transthoracalis Doppler-echokardiográfia, krónikus teljes koronáriaokklúzió

Transthoracic echocardiographic diagnosis of chronic total coronary artery occlusion

We report a case of a 59 years old male patient who reported chronic effort chest pain. Transthoracic Doppler echocardiography (TTDE) presented normal left ventricular systolic function with retrograde coronary artery blood flow in the distal and middle part of the left anterior descending artery (LAD). On the basis of findings of TTDE, we suspected chronic total occlusion (CTO) of the LAD, which was confirmed by invasive coronary angiography.

The LAD CTO was successfully opened by a catheter-based intervention. After the percutaneous coronary intervention, the patient became completely free of symptoms. The repeated TTDE study showed the cessation of reverse coronary blood flow and the return of the physiological antegrade flow in the LAD.

Keywords: transthoracic Doppler echocardiography, chroncic total coronary occlusion

A krónikus teljes koronáriaokklúzió (CTO) gyakori eltérés invazív koronarográfia során (1). Az utóbbi évek vizsgálatai igazolták, hogy ezen eltérések megnyitása életképes szívizom esetén a betegek prognózisát javítja (2-6). Az echokardiográfiás technika fejlődésével lehetővé vált a humán epikardiális koronáriák vizsgálata transthoracalis Doppler-echokardiográfiával (TTDE) (7,
8). Ennek során nemcsak a szükületekre jellemző artériás flow akceleráció jeleníthető meg, hanem egyes Doppler-echokardiográfiás eltérések alapján a CTO diagnózisa is felvethető. Közleményünkben effort jellegü mellkasi panaszokkal bíró beteg esetét mutatjuk be, akinél a TTDE az RDA-ban CTO-ra jellemző retrográd artériás koronáriaáramlást igazolt.

A kézirat 2021. 09. 01-jén érkezett a szerkesztőségbe, 2021. 09. 08-án került elfogadásra. 


\section{Esetismertetés}

Az 59 éves férfi beteget egy hónap óta fennálló effort jellegű mellkasi panasz miatt észleltük osztályunkon. Felvételekor fizikális státuszában jelentős eltérés nem volt, a 12 elvezetéses EKG-n jelentős kórosat nem láttunk, patológiás Q-hullám, ST-depresszió vagy ST-eleváció nem volt kimutatható. Felvételi laboratóriumi paramétereinél sorozatban elvégzett nekroenzimek (CK, Troponin) normális tartományban lévő értékeket mutattak. A felvételekor elvégzett TTE normális üregrendszert, enyhe balkamra-hipertrófiát mutatott, bal kamrai szisztolés falmozgászavar nem volt látható. Megfelelö beállítást követően az RDA disztális és középső, részét color Dopplerrel szkennelve jól látható volt az érben a reverz, fiziológiástól eltérő irányú artériás koronária-

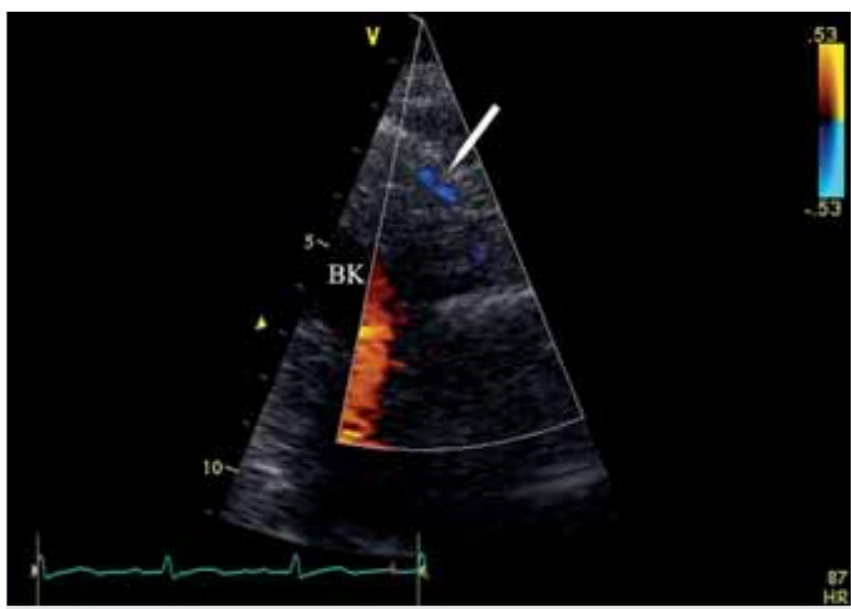

1. ÁBRA. A csúcsi apicalis módosított háromüregi 2D color Doppler-echokardiográfiás, diasztoléban megállított felvételen, a bal kamra elülső falának külső vetületén az RDAban kék színnel kódolt, a fiziológiással ellentétes irányú retrográd artériás koronáriaáramlás jeleníthető meg (fehér nyíl) $B K=$ bal kamra

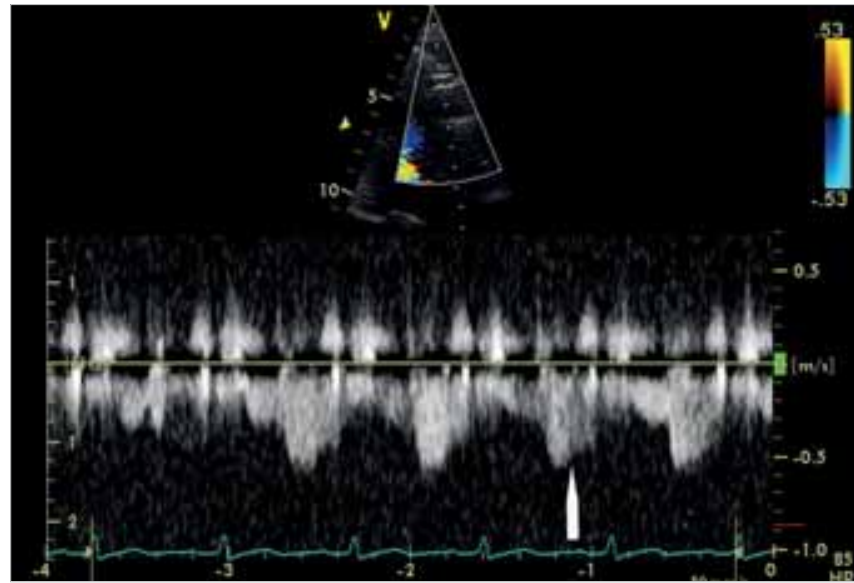

2. ÁBRA. A retrográd RDA-ból color vezérelt pulzatilis Dopplerrel felvett spektrumon reverz, normális sebességü, szisztolés és diasztolés koronáriaáramlás látható. $A$ diasztolés koronáriaáramlás domináns, jellegzetesen trapéz áramlási mintázatú (fehér nyíl) áramlás (1. ábra). Color vezérelt pulzatilis Dopplerrel az artériás koronáriaáramlásra jellemző bifázisos, inverz irányú, diasztolés dominanciájú áramlási spektrum volt megjeleníthető (2. ábra). A látott TTDE-kép alapján felvetettük az RDA krónikus teljes okklúziójának lehetőségét. Az invazív koronarográfia a proximális RDA CTOját igazolta fejlett epikardiális kollaterális rendszerrel (CC 2) a jobb koronária felöl (3. ábra). Második ülésben perkután intervenció történt az RDA CTO megnyitása céljából. Ennek során a 6F JR 4.0 felvezető katétert vezettünk a bal arteria radialison keresztül a jobb koronáriába, és 7F EBU 4.0 (mindkettő Launcher, Medtronic, USA) típusú katétert pedig a jobb arteria radialison keresztül a bal közös törzsbe. Az anterográd dróteszkaláció a Gaia-vezetődrót-család 2 és 3 keménységü eszközeivel (Asahi Intecc, Japán) sikertelennek bizonyult, ezért a jobb koronárián keresztül retrográd megközelítésre tértünk át. A retrográd Sion-drót (Asahi Intecc, Japán) bejutott az RDA disztális szeptális ágaiba, majd az RDA disztális valódi lumenébe (4. ábra). Ezt a drótot markerként használva ismét anterográd dróteszkalációs technikára tértünk át. Az Ultimate Bros 3 (Asahi

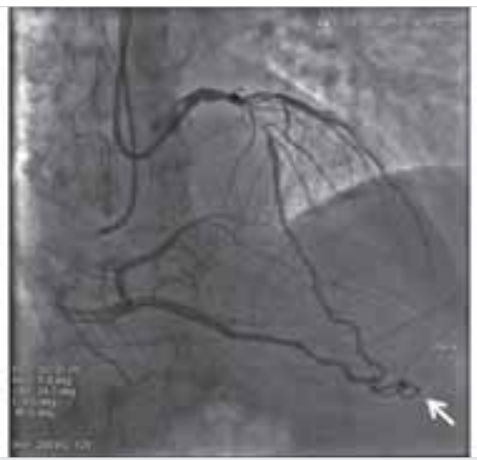

3. ÁBRA. A koronarográfiás felvételen a proximálisan teljesen elzáródott bal anterior descendens artéria látható, amelyet egy nagy apicalis kollaterális (fehér nyíl) táplál a jobb koronária felöl

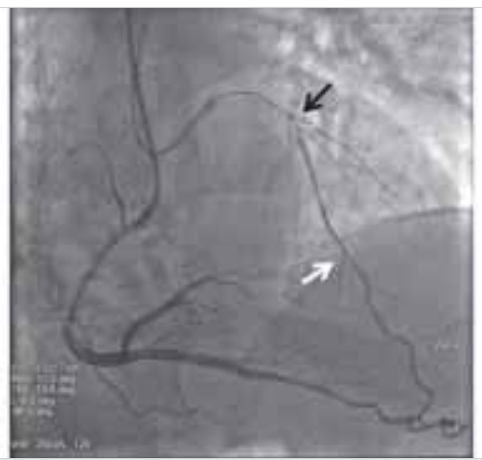

4. ÁBRA. A perkután koronáriaintervenció során az anterográd dróteszkalációs kísérlet sikertelen volt, a drót az RDA szubintimális terébe jutott (fekete nyíl). A jobb koronária felöl egy distalis szeptális kollaterálison keresztül a Sion-dróttal sikeresen jutottunk át retrográd irányból az RDA-ba (fehér nyíl) 


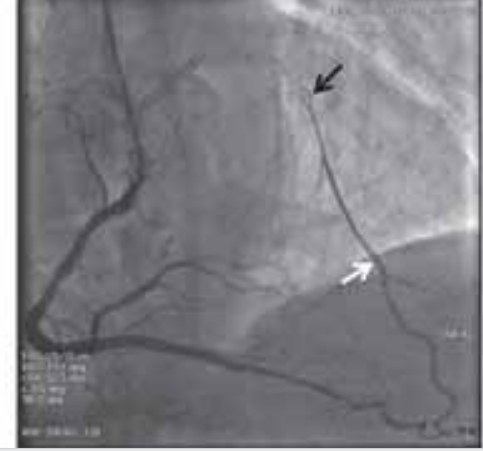

5. ÁBRA. Az anterográd dróteszkaláció újbóli próbálkozás után sikeresnek bizonyult (fehér nyíl), amelynél markerként a jobb koronária felöl felvezetett retrográd drótot használtuk (fekete nyíl)

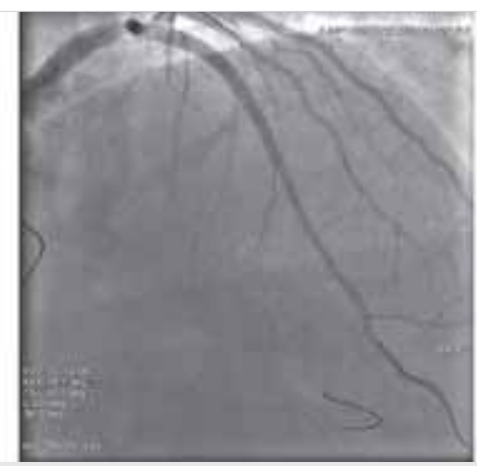

6. ÁBRA. A záró angiográfiás felvételen az RDA stent-implantáció utáni állapota látható reziduális szűkület nélkül

Intecc, Japán) vezetődróttal sikeresen áthatoltunk az okklúzión és a disztális valódi lumenbe jutottunk (5. ábra). Ezt követően $2 \mathrm{db}$ Synergy stentet implantáltunk az RDA-ba, és non-compliant ballonnal nagy nyomású utánfeszítéseket végeztünk. A záró angiográfiás felvétel igazolta a beavatkozás eredményeként kialakult TIMI 3 anterográd RDA-áramlást (6. ábra). A sikeres intervenciót követően color és pulzatilis Dopplerrel az RDA valamennyi szakaszán fiziológiás irányú, anterográd artériás koronáriaáramlási spektrum volt megjeleníthető (7-8. ábra).

\section{Megbeszélés}

A CTO előfordulása a koronáriabetegségben szenvedők között 18 és 52\% közötti prevalencia értéket mutat (1). Az obszervációs és a metaanalízis-vizsgálatok szignifikánsan rosszabb hosszú távú túlélést bizonyítottak azoknál, akiknél a főbb koronáriaágakban legalább egy elzáródás kimutatható (1). A perkután koronáriaintervenciók bevezetésekor, a kezdeti időszakban a beavatkozás sikeressége CTO esetén alig érte el az $50 \%$-ot. Az intervenciós eszközök, a kezelési stratégia és a technika fejlődése következtében ez az érték mára 85-90\%-ra nőtt. Vizsgálatok igazolták, hogy a CTO-k invazív katéteres intervencióval történő megnyitása életképes szívizom esetén a prognózist javítja (2-7). A kardiológiai UH-vizsgálómódszerek fejlődése lehetővé tette a főbb koronáriaágak TTDE-s vizsgálatát, amelynél az RDA megjelenítése jár a legnagyobb sikerrátával $(8,9)$. A koronáriák szűkületeinek TTDE-vel történő megítélését az érben fellépő lokális sebességgyorsulások, valamint ettől proximálisan, illetve disztálisan mérhető Doppleres áramlási sebességadatok teszik lehetővé. Az utóbbi egy évtizedben a koronáriaszűkületek TTDE-s diagnosztikájának térhódítása mellett előtérbe került a krónikus koronáriaokklúziók TTDE-vel történő diagnosztizálása is. Watanabe és munkatársai kimutatták, hogy az RDA-rendszerben észlelt reverz áramlás $93 \%$-os érzékenységgel és $100 \%$-os specificitással

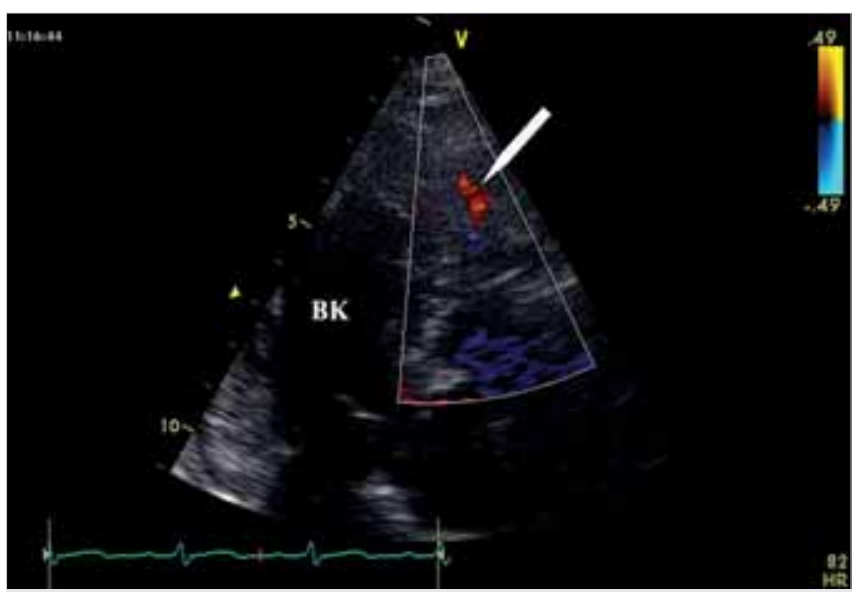

7. ÁBRA. A sikeres perkután koronáriaintervenciót követően a csúcsi apicalis módosított háromüregi 2D color Doppler-echokardiográfiás, diasztoléban megállított felvételen a bal kamra elülső falának külső vetületén az RDA-ban piros színnel kódolt, fiziológiás irányú artériás koronáriaáramlás jeleníthető meg (fehér nyíl). (BK = bal kamra)

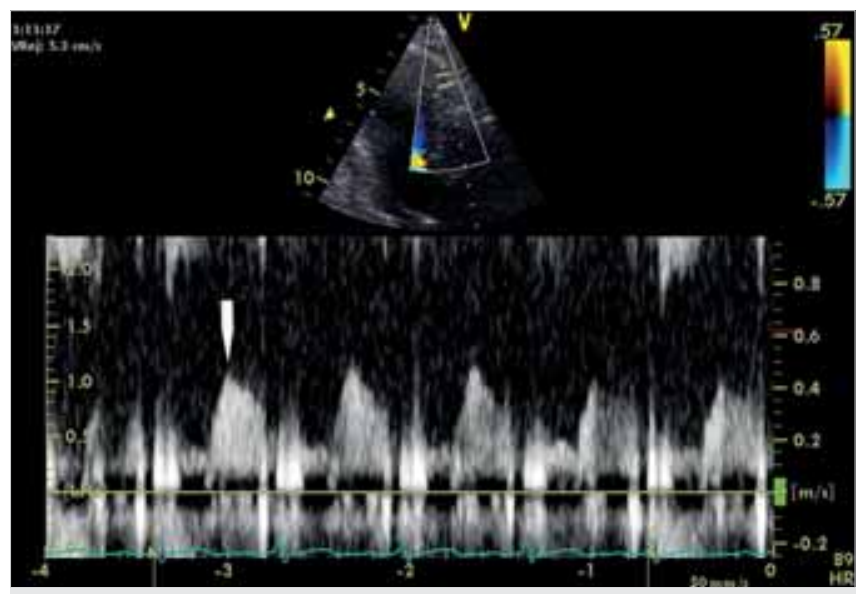

8. ÁBRA. Az RDA-áramlásból color vezérelt pulzatilis Dopplerrel fiziológiás, anterográd, koronáriaáramlási spektrum látszik, amelyen a diasztolés koronáriaflow a domináns, jellegzetes trapéz mintázatú (fehér nyíl) 
bír a proximális RDA CTO kimutatására vonatkozóan (10). A föbb koronáriaágak TTDE-s vizsgálata mellett a kamrai szeptális koronáriaartériák áramlási irányának és azok csúcssebesség értékének vizsgálata nyújthat diagnosztikus segítséget a CTO-k kimutatásában (11). A TTDE-s módszer előnye más vizsgálóeszközökhöz viszonyított az alacsonyabb költség, az ionizáló sugárzástól mentes müködés és a szélesebb körü hozzáférés. A vizsgálóeszköz hátránya, hogy elsajátítása speciális eszközbeállításokat és a megfelelő metszetek létrehozása nagy gyakorlatot igényel.

\section{Következtetések}

Esetünk alapján a TTDE-vel kimutatott fordított irányú koronáriaáramlási mintázat alkalmas az RDA CTO diagnózisának felvetésére.

\section{Nyilatkozat}

A szerzők kijelentik, hogy az esetismertetés megírásával kapcsolatban nem áll fenn velük szemben pénzügyi vagy egyéb lényeges összeütközés, öszszeférhetetlenségi ok, amely befolyásolhatja a közleményben bemutatott eredményeket, az abból levont következtetéseket vagy azok értelmezését.

Irodalom

1. Fefer $P$, Knudtson ML, Cheema AN, et al. Current perspectives on coronary chronic total occlusions: The Canadian multicenter chronic total occlusions registry. J Am Coll Cardiol 2012; 59: 991-997.

https://doi.org/10.1016/j.jacc.2011.12.007

2. Toma A, Gick M, Minners J, et al. Survival after percutaneous cor- onary intervention for chronic total occlusion. Clin Res Cardiol 2016; 105: 921-929. https://doi.org/10.1007/s00392-016-1000-2

3. Teramoto T, Tsuchikane E, Yamamoto M, et al. Successful revascularization improves long-term clinical outcome in patients with chronic coronary total occlusion. IJC Heart \& Vasculature 2017; 14: 28-32. https://doi.org/10.1016/j.ijcha.2016.11.001

4. Khan MF, Wendel CS, Thai HM, et al. Effects of percutaneous revascularization of chronic total occlusions on clinical outcomes: A meta-analysis comparing successful versus failed percutaneous intervention for chronic total occlusion. Cath Cardiovasc Interventions 2013; 82: 95-107. https://doi.org/10.1002/ccd.24863

5. Hoebers LP, Claessen BE, Elias J, et al. Meta-analysis on the impact of percutaneous coronary intervention of chronic total occlusions on left ventricular function and clinical outcome. Int J Cardiol 2015; 187: 90-6. https://doi.org/10.1016/j.ijcard.2015.03.164

6. Mehran R, Bimmer E. Claessen, et al. Long-Term outcome of percutaneous coronary intervention for chronic total occlusions. J Am Coll Cardiol Cardiovasc Interv 2011; 9: 952-961.

https://doi.org/10.1016/j.jcin.2011.03.021

7. Tajti $P$, Ungi I. Az anterográd technikák szerepe a krónikus teljes koszorúér-elzáródás perkután revaszkularizációjában. Cardiologia Hungarica 2018; 48: 330-339.

https://doi.org/10.26430/CHUNGARICA.2018.48.5.330

8. Krzanowski M, Bodzon W, Dimitrow PP. Imaging of all three coronary arteries by transthoracic echocardiography: an illustrated guide. Cardiovascular Ultrasound 2003; 1: 16.

https://doi.org/10.1186/1476-7120-1-16

9. Pálinkás A, Varga A, Sepp R, Ruzsa Z, Ungi I, Forster T, Csanády M. Koronáriaszűkület diagnózis transthoracalis echokardiográfiával. Cardiologia Hungarica 2002; 32:95-96.

10. Watanabe N, Akasaka T, MD, Yamaura Y. et al. Noninvasive detection of total occlusion of the left anterior descending coronary artery with transthoracic Doppler echocardiography. J Am Coll Cardiol 38: 1328-32. https://doi.org/10.1016/s0735-1097(01)01556-x 11. Vegsundvåg J, Holte E, Wiseth R, Hegbom K, Hole T. Coronary artery occlusions diagnosed by transthoracic Doppler. Cardiovascular Ultrasound 2014; 12: 12. https://doi.org/10.1186/1476-7120-12-12 